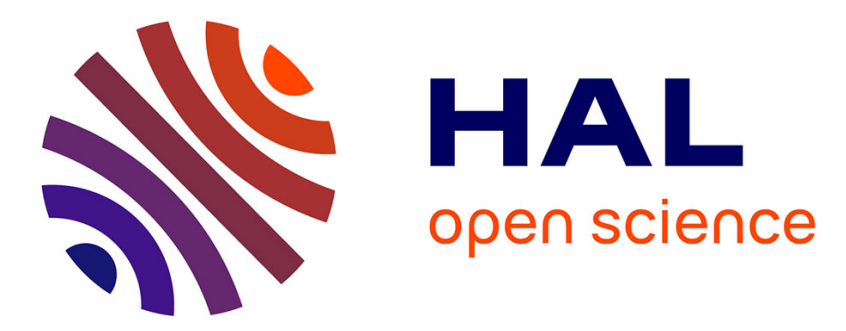

\title{
Growing Prospects of Dynamic Covalent Chemistry in Delivery Applications
}

\author{
Sébastien Ulrich
}

\section{To cite this version:}

Sébastien Ulrich. Growing Prospects of Dynamic Covalent Chemistry in Delivery Applications. Accounts of Chemical Research, 2019, 52 (2), pp.510-519. 10.1021/acs.accounts.8b00591 . hal-02322101

\section{HAL Id: hal-02322101 \\ https://hal.science/hal-02322101}

Submitted on 18 Nov 2020

HAL is a multi-disciplinary open access archive for the deposit and dissemination of scientific research documents, whether they are published or not. The documents may come from teaching and research institutions in France or abroad, or from public or private research centers.
L'archive ouverte pluridisciplinaire HAL, est destinée au dépôt et à la diffusion de documents scientifiques de niveau recherche, publiés ou non, émanant des établissements d'enseignement et de recherche français ou étrangers, des laboratoires publics ou privés. 


\section{The growing prospects of dynamic covalent}

\section{chemistry in delivery applications}

Sébastien ULRICH*

IBMM, Université de Montpellier, CNRS, ENSCM, UM, Montpellier, France.

\section{CONSPECT US}

Delivery remains a major obstacle restricting the potential action of small molecular drugs as well as novel biologics which cannot readily enter cells without the help of a vector. A successful active delivery process involves three steps: a) tagging the drug with a vector, b) effective trafficking of this [drug-vector] conjugate through biological barriers, and finally c) controlled drug release. While covalent bond formation and/or supramolecular association is involved in the making of the [drug-vector] conjugate, the final step requires precisely a controlled dissociation in order to trigger drug release. Therefore, in pursuit of smart, effective and non-toxic delivery systems,

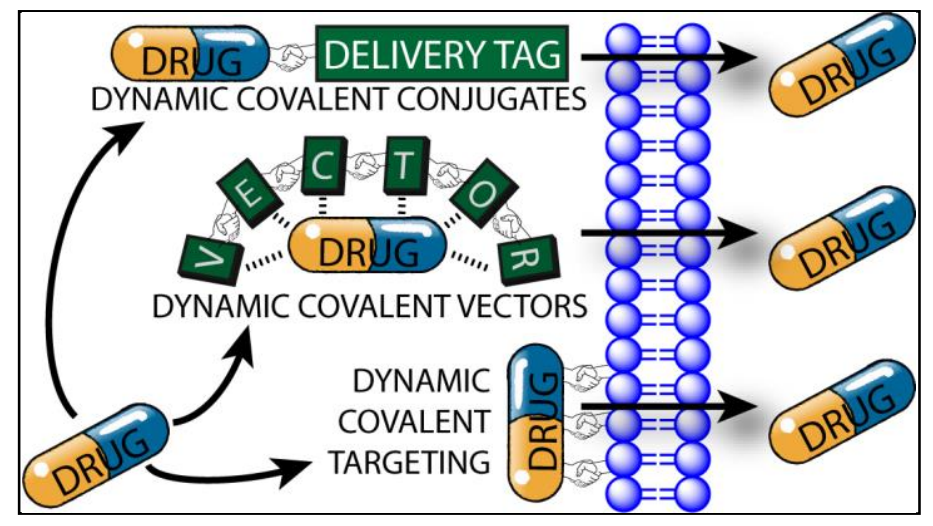
it has become widely recognized that a control over dynamic self-assembly could unleash the efficacy of artificial vectors.

In this Account, I discuss our endeavours, and those of colleagues, in the recent implementation of Dynamic Covalent Chemistry (DCvC) in delivery applications. DCvC exploits reversible covalent reactions to generate covalent systems that can self-fabricate, adapt, respond, and fall apart in a controlled fashion. A privileged set of reversible covalent reactions has emerged in the community working on delivery applications and is based on: condensation reactions (imine, acylhydrazone, oxime), disulfide, and boronate ester formations. The latest developments making this chemistry particularly attractive for such a DCvC approach are discussed. The rational justifying the potential of DCvC in delivery is based on the principle that using such reversible covalent reactions afford transient [drug-vector] conjugates which form spontaneously and chemoselectively, then adapt and self-correct their structure during self-assembly and trafficking thanks to the dynamic nature of the reversible covalent bonds, and finally respond to physico-chemical stimuli such as $\mathrm{pH}$ and redox changes, thereby enabling controlled dissociation and concomitant drug release. For these reasons, $\mathrm{DCvC}$ has recently emerged as a leverage tool with growing prospects for advancing toward smarter delivery systems. The implementation of $\mathrm{DCvC}$ can follow three approaches that are discussed herein: 1) dynamic covalent bioconjugates, involving the transient covalent conjugation with a vector, 2) dynamic covalent vectors, involving the controlled dynamic and adaptive assembly and disassembly of vectors that complex drugs through supramolecular association, and 3) dynamic covalent targeting, involving the transient 
chemoselective formation of covalent bonds with the constituents of cell membranes.

While DCvC has already attracted interest in material sciences, the recent results described in this Account showcase the vast potential of $\mathrm{DCvC}$ in biological sciences, and in particular in delivery applications where self-fabricated, adaptive, and responsive devices are of utmost importance.

\section{INTRODUCTION}

Reversible reactions were seen for a long time in the history of organic chemistry as undesired because they proceed with low conversions, low reaction yields, and lead to unstable products. This view has drastically changed during the last two decades thanks to the development of dynamic covalent chemistry $(\mathrm{DCvC})^{1-4}$ which revealed a unique feature of chemical systems built using reversible reactions: they can form, adapt, respond, and fall apart in a dynamic fashion in response to changes in medium composition, in physical parameters (temperature, concentration, etc), or in the presence of complementary or templating partners. ${ }^{5,6}$ While noncovalent assemblies are by essence dynamic and adaptive on the supramolecular level, $\mathrm{DCvC}$ provides an access to dynamic and adaptive covalent systems which may be more robust and easier to characterize. In that sense, the field of $\mathrm{DCvC}$ perfectly fits the missing gap between the colloquial representation of static molecular chemistry and labile supramolecular chemistry (Figure 1).

\section{DYNAMIC COVALENT CHEMISTRY \\ Thermodynamically stable}

\&

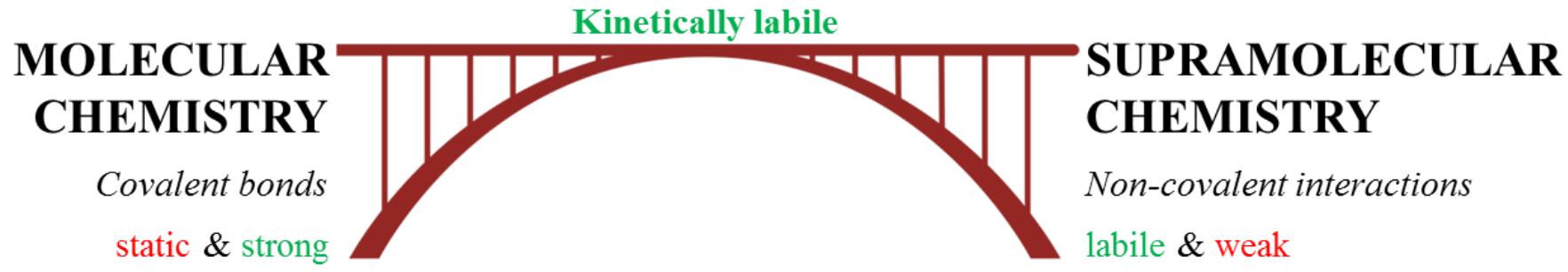


Figure 1. Representation of dynamic covalent chemistry as a bridge between molecular and supramolecular chemistry, enabling access to covalent and stable yet dynamic molecular assemblies.

Back in the 90's, dynamic combinatorial chemistry emerged as a first implementation of DCvC in medicinal chemistry. ${ }^{7-9}$ Simply by analysing the constitutional changes that result from selective templating effects in the presence of a biological target, one can identify, in a one-pot process, the best-fitted compounds which are self-amplified. Although it comes with the analytical challenge of characterizing complex mixtures, this approach beautifully exploit the adaptive behaviour of dynamic chemical systems. $\mathrm{DCvC}$ has then been particularly used in material sciences for making self-fabricating materials such as dynamic polymers, responsive sensors, adaptive membranes, and dynamic networks that display controlled degradation, constitutional adaptation or self-healing properties. ${ }^{10-13}$ However, the deliberate application of $\mathrm{DCvC}$ in biological sciences is a much more recent adventure. ${ }^{14}$ In this Account, I summarize the most significant progresses recently made in delivery applications where dynamic covalent systems can be particularly impactful.

\section{RATIONAL FOR USING DYNAMIC CHEMISTRY IN DELIVERY APPLICATIONS}

Delivery remains a major and central issue restricting the action of small molecule drugs and novel biologics (e.g. DNA, siRNA, miRNA, proteins, enzymes). The recent introduction of supramolecular design principles (i.e. autonomous, programmed or adaptive, dynamic selfassemblies) has opened up an interesting new direction in delivery applications where the design of "smart" dynamic and responsive vehicles is of utmost importance. ${ }^{15}$ Indeed, an active delivery process requires tagging a vector to transport a drug that would otherwise not cross biological 
barriers or be quickly degraded by endogenous enzymes. Three steps are critical in this process: 1) drug-vector association, then 2) trafficking of the [drug-vector] complex through biological barriers, and finally 3 ) drug release. While adaptive self-assembly must be important in the first two steps, controlled disassembly is clearly essential for the last step. Therefore, the design of vectors that transiently associate with a drug, and not permanently like non-dynamic macromolecular vectors, should therefore represent a major improvement in the field with a strong potential for enhancing the efficacy of delivery.

\section{REVERSIBLE COVALENT REACTIONS SUITED FOR DELIVERY APPLICATIONS}

Choosing appropriate reversible covalent reactions is critical in a $\mathrm{DCvC}$ approach as it will define the thermodynamic and kinetic features of the system. Ideally for biological applications, self-assembly should take place at low concentration within a reasonable time-scale, operate chemo-selectively in aqueous media at ambient temperature, yield stable assemblies, and at the same time display an appropriate degree of controlled dissociation and fast responsiveness.

Because of these criteria, carbonyl condensation reactions (imine, acylhydrazone, oxime), disulfide and boronate ester formations have become a very popular set of reactions in $\mathrm{DCvC}$ geared toward bioapplications (Scheme 1). One sensible reason is the relatively straightforward introduction of aldehydes/ketones, amine/hydrazine/hydrazide/aminooxy, thiols, and boronic acids into small molecules and biomolecules such as peptide/proteins and nucleic acids. 


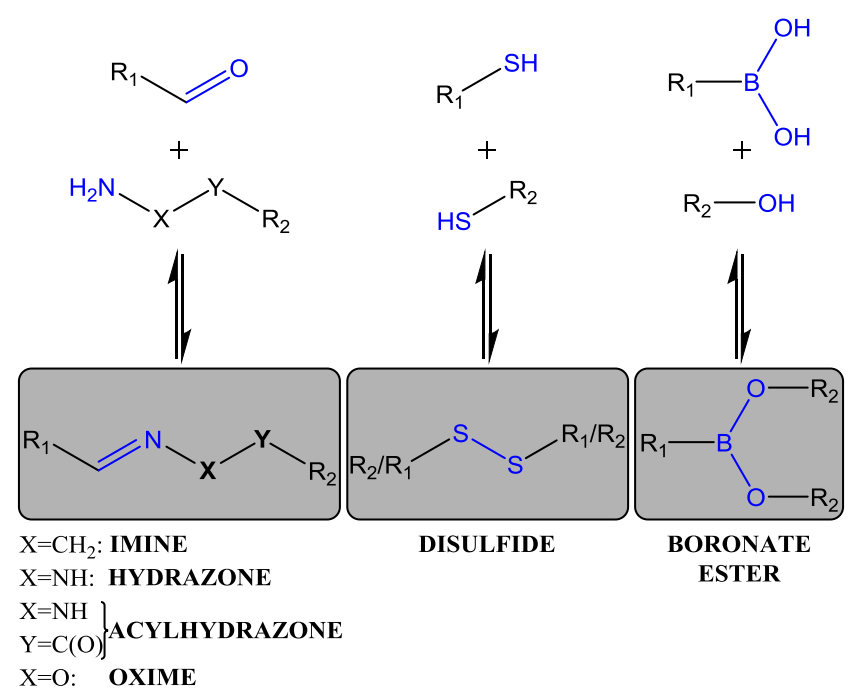

Scheme 1. Formation and structures of the most popular reversible covalent linkages used in delivery applications by $\mathrm{DCvC}$.

Condensation reactions. While imines usually show poor chemoselectivity and weak stability in aqueous media, oximes are stable linkages often used in bioconjugation. ${ }^{16,17}$ In between, acylhydrazones form chemoselectively in mild aqueous conditions, yet they remain dynamic and can be hydrolysed in acidic conditions or exchanged by other hydrazides within hours. Their formation usually requires weak acid catalysis and proceeds sluggishly at neutral physiological $\mathrm{pH}$. However, molecular engineering has recently led to the identification of fast $\alpha$ nucleophiles, ${ }^{18-20}$ nucleophilic catalysts, ${ }^{21-25}$ and active buffers ${ }^{26}$ that dramatically speed up the kinetic of (acyl)hydrazone and oxime formation and exchange, even at neutral pH (e.g. full oxime formation achieved within $1 \mathrm{~h}$ at low $\mu \mathrm{M}$ concentration in biological buffer, $\mathrm{pH} 7.4^{26}$ ), making it a more practical tool for biological applications which use low concentration of reactants and physiological $\mathrm{pH}$. The reversibility of these condensation reactions has been obviously exploited by dynamic combinatorial chemistry, but also in biological applications, for instance to reverse formaldehyde fixing of cells. ${ }^{27}$ Interestingly for delivery applications, 
acylhydrazones are acid-sensitive. They are typically hydrolysed at acidic $\mathrm{pH}(\mathrm{pH} \approx 4-6)$ which is advantageous for triggering release in tumour tissues $(\mathrm{pH} \approx 6)$ or following endocytic cell internalization (late endosomes have $\mathrm{pH} \approx 5.0-5.5$ ). ${ }^{28}$

Disulfides. Disulfide formation is a reversible redox process: oxidation of thiols triggers disulfide formation whereas reduction triggered by the reductive intracellular environment caused by the high concentration (mM) of glutathione converts disulfides into thiols. Additionally, disulfides can exchange in mild basic conditions ( $\mathrm{pH} 7-8)$ through a nucleophilic displacement mechanism involving the thiolate attack on the disulfide. ${ }^{29}$

Boronate esters. Boronate esters formation occurs in aqueous media by the reaction of boronic acids with diols and the frequent occurrence of 1,2- and 1,3-diols in saccharides has opened new applications for this reaction in delivery. Similarly to condensation reactions, the thermodynamic parameters of boronate ester formation can be optimized through substituent effects. For instance, Hall and co-workers have identified a click biorthogonal boronate that form reversibly within minutes at low micromolar concentration in water and with sufficient stability $\left(\mathrm{K}_{\mathrm{eq}} \approx 10^{5}-\right.$ $\left.10^{6} \mathrm{M}^{-1}\right) .^{30}$

\section{DYNAMIC COVALENT BIOCONJUGATES}

Tagging a cell-impermeable drug with a delivery vector is often not a transparent chemical modification and can be detrimental to the efficacy of the drug. This is why a dynamic approach which enables the controlled insertion, then the dissociation of the delivery tags triggering the subsequent release of the unmodified original drug can be highly beneficial. 
Boronic acids were already proposed in the mid 90's for the delivery of sugars into liposomes through the transient and reversible formation of boronate linkages. ${ }^{31,32}$ In 2015, Gale and coworkers reported a dynamic covalent approach to the transmembrane transport of amino acids in vesicles. ${ }^{33}$ Their approach exploits an early finding that water-soluble aldehydes such as formaldehyde, acetaldehyde and pyridoxal, facilitate the diffusion of several amino-acids across lipid membranes, possibly due to a transient covalent self-assembly rendering the corresponding product more lipophilic - thus capable of diffusing through the membrane - while hydrolysis then releases the free amino-acid after diffusion. ${ }^{34}$ The authors designed an elegant threecomponent self-assembly system made of an amino-acid (glycine), a hydrogen bonding donor (squaramide) to bind the carboxylate group, and a lipophilic aldehyde for binding the amino group through imine/hemiaminal formation (Figure 2). The results revealed a synergistic effect of the dual binders and demonstrated the key role of $\mathrm{DCvC}$ through hemiaminal formation which promotes transmembrane diffusion. 


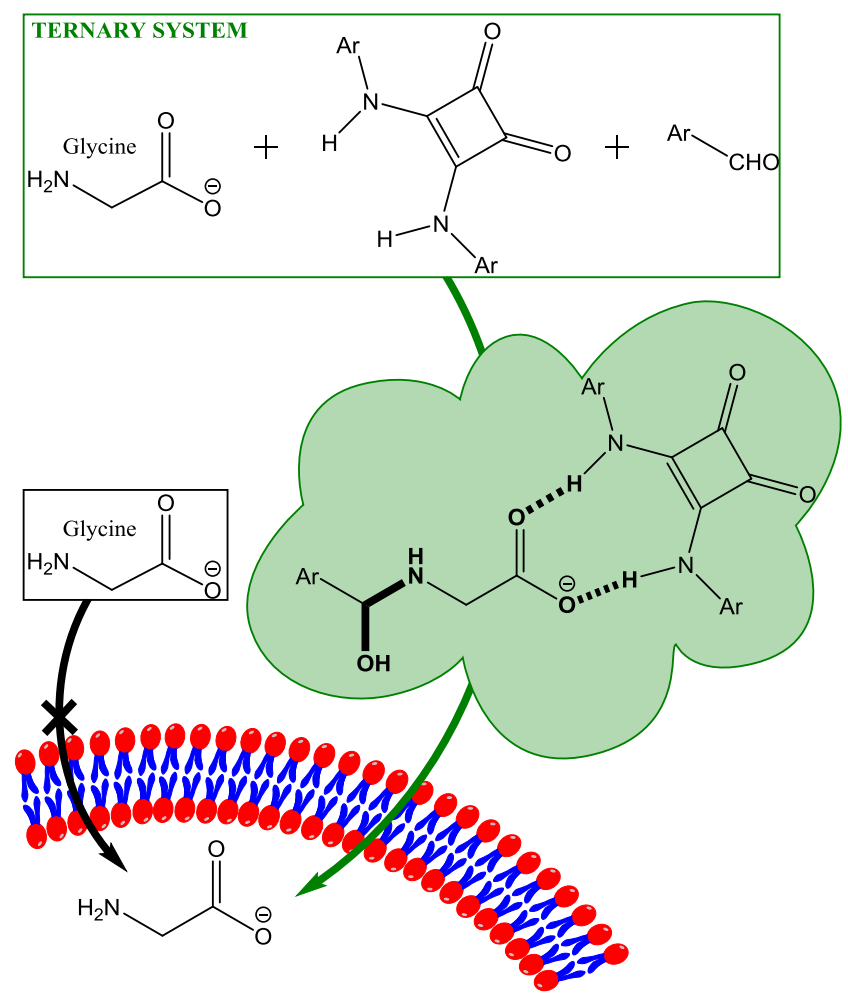

Figure 2. Principle of transmembrane transport of glycine by combining supramolecular interactions and dynamic covalent chemistry in a three-component self-assembly. Ar: 3,5bis(trifluoromethyl)-benzene.

\section{DYNAMIC COVALENT VECTORS}

Vectors that complex drugs through non-covalent interactions are part of a supramolecular delivery approach that has become very popular in gene delivery. Oligonucleotides do not effectively pass through cell membranes because of hydrophilicity and charge repulsion with cell membrane constituents, and are also easily degraded by endogenous nucleases. As a result, vectors that protect them from this degradation and assist their intracellular delivery are very much needed. Synthetic vectors based on cationic macromolecules were first explored to this end. ${ }^{35,36}$ However, these non-dynamic vectors suffer from their inability to release the transported oligonucleotides after cell penetration, and their non-degradability lead to 
accumulation within cells and toxic side-effects. Thus, synthetic vectors have unfortunately not yet outpaced viral vectors, ${ }^{37}$ and smarter designs are needed. ${ }^{38-40}$ Several groups including ours have therefore recently implemented a DCvC approach in order to generate smart vectors that self-assemble, adapt and degrade in a controlled manner.

Covalent vectors by self-assembly. In 2012, we initiated a research program on dynamic covalent polymers (DCPs) ${ }^{11}$ for gene delivery. We were particularly interested in inserting the reversible covalent linkage within the main-chain of these polymers, with the general objective of obtaining dynamic polymers that can grow in the appropriate conditions and/or in the presence of a templating oligonucleotide while being susceptible to acid-triggered degradation. Our reasoning is that this growth and collapse process should switch on and off, respectively, multivalent interactions that are commonly at play when complexing nucleic acids. Our first generation of DCPs results from the covalent self-assembly of cationic bisaldehydes with short pegylated bishydrazides, respectively (Figure 3A). ${ }^{41}$ Polymer formation, occurring through a polycondensation under thermodynamic control, was evidenced by DOSY-NMR above a threshold concentration of $10 \mathrm{mM}$, while macrocycles predominate in dilute solutions. The DCPs can undergo hydrolytic depolymerization at acidic $\mathrm{pH}(4-5)$ in aqueous media or by treatment with methoxyamine that operate hydrazone-to-oxime covalent exchanges, while being stable at neutral $\mathrm{pH}$. Finally, both ethidium bromide displacement assays and gel electrophoresis confirmed the ability of these DCPs to effectively complex DNA through multivalent interactions, whereas the starting cationic monomers remain inactive. Recently, we have reported the design of a second generation of DCPs that incorporates modified amino acids building blocks and, in addition to the acid-sensitive acylhydrazones, redox-sensitive disulfides, thereby enabling access to multi-component and multi-dynamic biomolecular DCPs ${ }^{42}$ by covalent self- 
assembly (Figure $3 \mathrm{~B}) \cdot{ }^{43}$ We have found that these short DCPs $(\mathrm{DP} \approx 7)$ effectively condense not only DNA but also siRNA. Nanoparticles of 70-160 nm in diameter have been characterized by dynamic light scattering and cell studies have demonstrated an effective delivery and knockdown of luciferase activity in a MCF7-Luc cell line.

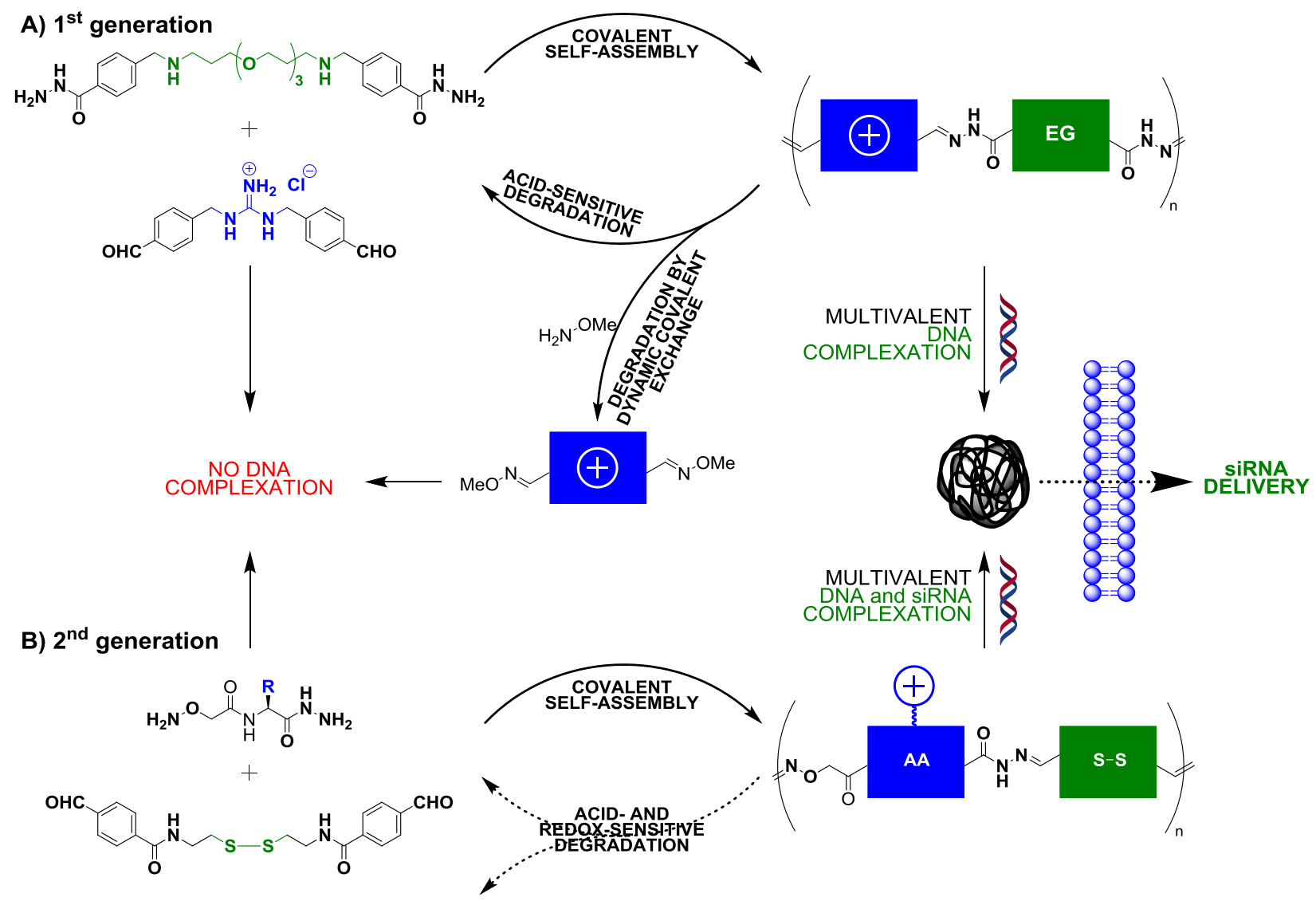

Figure 3. Covalent self-assembly of dynamic covalent polymers for DNA complexation and siRNA delivery. A) example of $1^{\text {st }}$ generation of cationic polyacylhydrazones; B) $2^{\text {nd }}$ generation incorporating modified amino acids and redox-sensitive disulfides.

Using the same acylhydrazone technology, Fernandez-Trillo, Montenegro and co-workers have described in 2016 the side-chain functionalization of polyhydrazide polymer scaffolds of different lengths through multiple acyhydrazones and their use for siRNA and DNA plasmid 
delivery. ${ }^{44,45}$ This concept ${ }^{46}$ has been subsequently extended to $\alpha$-helical peptide scaffolds ${ }^{47}$ with a successful application in gene edition. ${ }^{48}$ Different combinations of complementary cationic head groups and lipophilic tails were screened - exploiting elegantly the synthetic versatility of the $\mathrm{DCvC}$ screening approach that was initially reported in the Matile group in the context of amphiphilic transporters of polyions (Figure 4A) $)^{49-52}$ - and effective vectors for the delivery of siRNA were identified. While working on peptide-based cationic clusters for DNA complexation, we also reported in 2015 a similar fragment screening approach using a fluorescence assay on a 96-well plate format that enable the rapid testing of different types of peptide scaffolds and binding groups (Figure 4B). ${ }^{53}$ We selected the most effective DNA binders, composed of a cyclic peptide grafted with multiple cationic side groups, and subsequently tested siRNA complexation and siRNA delivery, achieving the successful identification of an effective vector that deliver siRNA in living cells. 
A) Post-functionalization of polymer scaffolds by DCvC

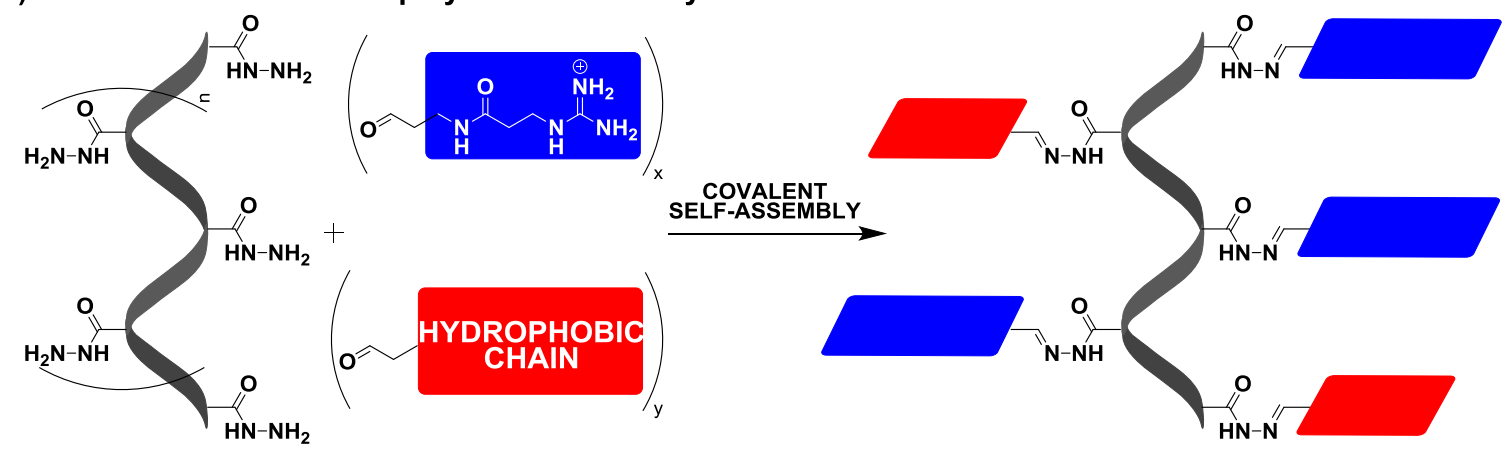

B) Fragments screening DCvC

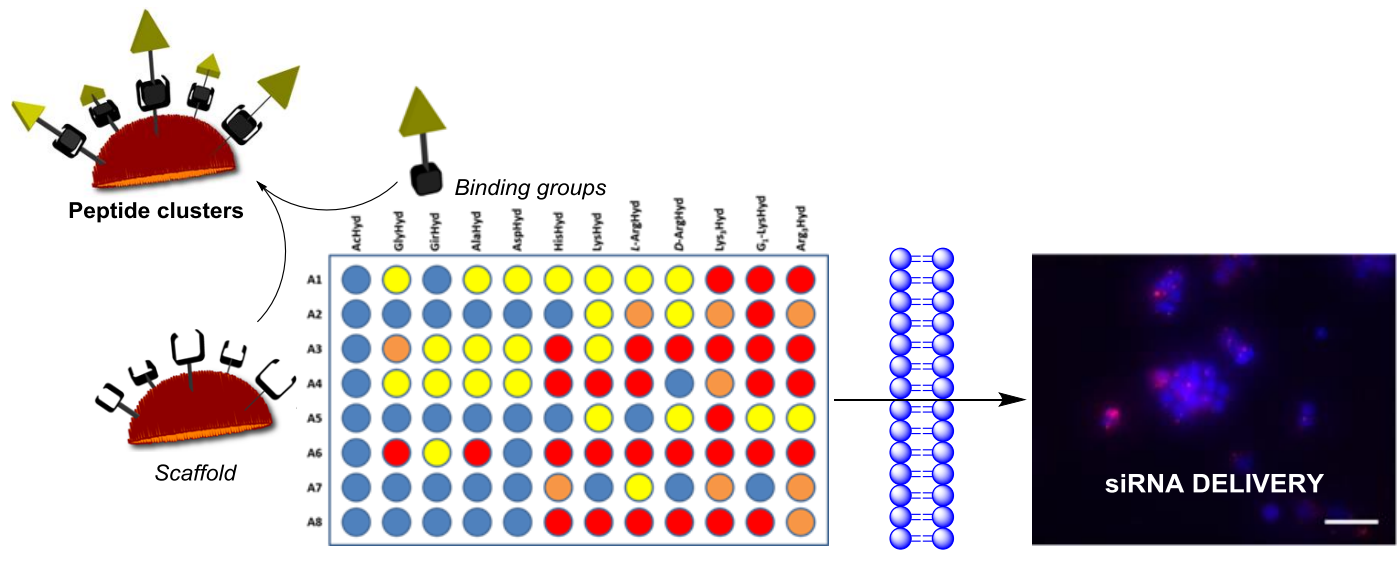

Figure 4. Post-functionalization of scaffolds by DCvC. A) amphiphilic polyhydrazones; B)

cationic peptide clusters. Fragments screening is illustrated through a 96-well plate fluorescence assay that enable identification of DNA binders, which were then successfully tested in siRNA delivery. Adapted with permission from ref. 53. Copyright 2015 The Royal Society of Chemistry.

The trend of going toward self-fabricated vectors has also been applied to disulfide-based systems. Early on, examples from the groups of Behr and Rice have pointed out that in situ cross-linking through disulfide formation enhances nucleic acid condensation into peptide-based nanoparticles. ${ }^{54-56}$ Then it was shown that poly-L-lysines appended with thiol groups at both $\mathrm{N}$ and $\mathrm{C}$ termini undergo oxidative step-growth polymerization, yielding cationic polymers capable of delivering DNA in cells. ${ }^{57}$ More recently, oligoarginine cell-penetrating peptides equipped 
with terminal cysteines were shown to readily penetrate cells in oxidative condition that trigger disulfide bridge formation. ${ }^{58}$ Using ring-opening polymerization, Matile and co-workers created, in a one-step substrate-initiated synthesis, ${ }^{59}$ cationic poly(disulfide)s for the intracellular and redox-sensitive delivery of fluorescence dyes, small-molecule drugs, and even proteins, ${ }^{60}$ liposomes and polymersomes ${ }^{61}$ (Figure 5). ${ }^{62}$

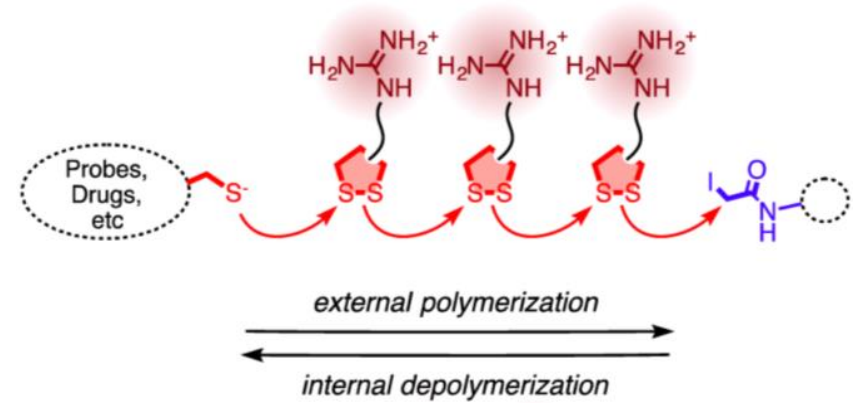

Figure 5. Ring opening polymerization of cyclic disulfides for the generation of cationic cellpenetrating poly(disulfide)s. Reproduced with permission from ref. 59. Copyright 2013 American Chemical Society.

Exploring the combination of $\mathrm{DCvC}$ with orthogonal self-assembly processes, we have recently reported on the coordination-driven self-assembly of multivalent metallo-supramolecular assemblies for DNA complexation. ${ }^{63,64}$

Adaptive self-assembly. Whereas these examples follow more a programmed self-assembly process where the structure of building blocks dictate the nature of the resulting self-assembly, the dynamic of systems that are build using reversible covalent reactions make them adaptive and capable of self-correction in the presence of oligonucleotides. Several examples have reported structural adaptation of supramolecular complexes to templating oligonucleotides. ${ }^{65-67}$ We have tested the constitutional adaptation of dynamic combinatorial libraries of multivalent cationic peptide-based clusters to the presence of DNA. A series of competition experiments, 
where neutral and cationic hydrazides compete for a single tetraaldehyde peptide scaffold, led to the conclusion that, in the appropriate non-dissociative conditions, DNA act as a template that induces the thermodynamic selection of the best fragments, through component exchange and template-accelerated ligation, and the amplification of the most active assembly from the mixture (Figure 6A) ${ }^{68}$ This approach alleviates the need for screening approaches and may lead to improved binders that are self-fitted to the target. The group of Barboiu has also proposed such approach using imine-based dynamic covalent frameworks (Figure 6B). ${ }^{69-72}$

A)

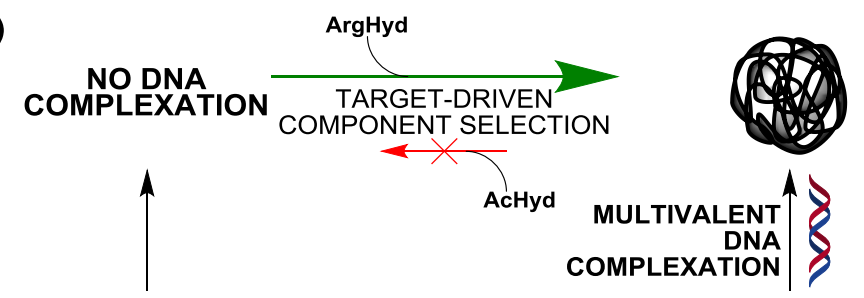

B)

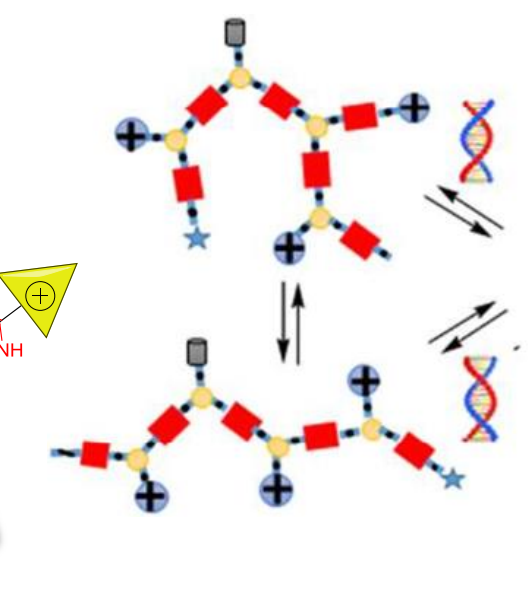

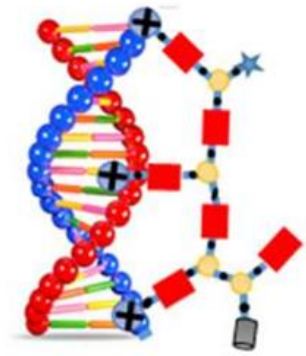

Figure 6. Constitutional adaptation of A) peptide clusters (adapted with permission from ref. 68 .

Copyright 2015 Wiley-VCH) and B) dynamic covalent frameworks to templating DNA (reproduced with permission from ref. 70. Copyright 2015 The Royal Society of Chemistry).

Also in 2015, while working on guanidinium-based molecular glues for multivalent biomolecular recognition, ${ }^{73}$ the group of Aida came across a small water-soluble tetraguanydilated dithiol which undergo a template-assisted oxidative polymerization in presence of siRNA, leading to polydisulfide nanocaplets of small and uniform size. ${ }^{74}$ Depolymerization in the reductive cytosolic environment was shown to liberate the packaged siRNA (Figure 7). 
(a)

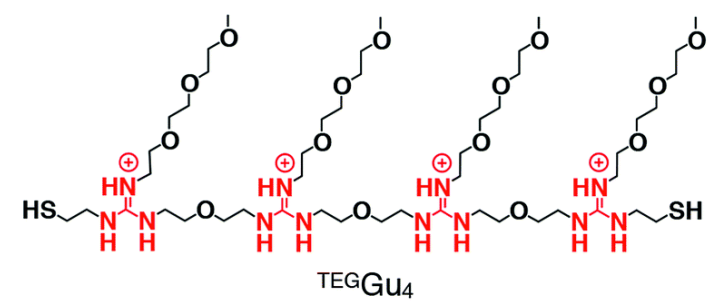

(b)
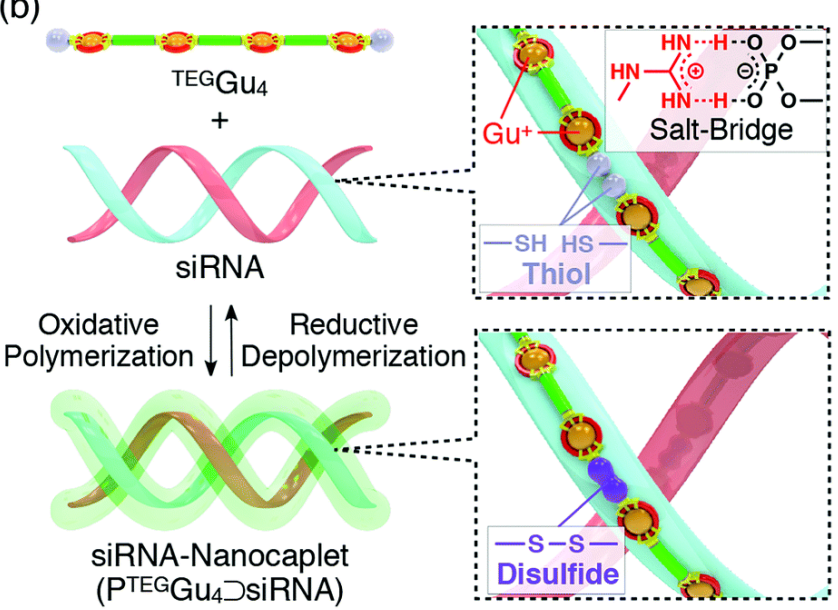

Figure 7. Templated polymerization. (a) Molecular structure of water-soluble tetraguanydilated dithiol ${ }^{\mathrm{TEG}} \mathrm{Gu}_{4}$; (b) principle of siRNA-templated oxidative polymerization and reductive depolymerisation. Reproduced with permission from ref. 73. Copyright 2017 The Royal Society of Chemistry.

Besides the constitutional adaptation to templating oligonucleotides, Matile and co-workers have found that $\mathrm{DCvC}$, and specifically disulfide exchange, can also occur on cell membranes during the trafficking toward cell entry (Figure 8). Intermediate disulfides with the transferrin receptor were found by proteomic analysis to be involved in the cell internalization mechanism of cyclic disulfides, ${ }^{75}$ showing an improvement in cell uptake with increasing ring tension. ${ }^{76,77}$

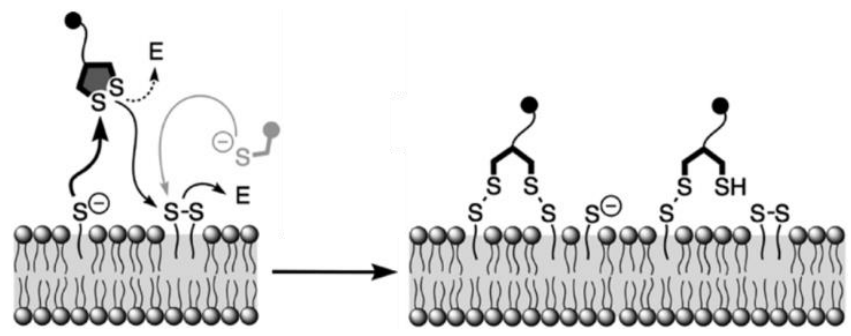


Figure 8. Principle of receptor-mediated $\mathrm{DCvC}$ occurring on cell membranes and promoting the internalization of cyclic disulfides. Adapted with permission from ref. 77. Copyright 2015 Wiley-VCH.

Controlled disassembly. $\mathrm{DCvC}$ also enables imposing constitutional changes for modulating or switching bioactivity. In the context of gene delivery, it is particularly interesting to be able to trigger decomplexation in a controlled fashion. For instance, disulfide reduction can be triggered by the intracellular environment and lead to vector degradation and concomitant drug release. ${ }^{78}$ The cationic poly(disulfide)s of Matile were found to depolymerize rapidly within minutes after intracellular reduction, which minimized their toxicity. ${ }^{59,79}$ Rapidly depolymerizing poly(disulfide)s enter cytosol where they release their cargo upon intracellular reduction, while slower depolymerizing poly(disulfide)s can transit to cell nuclei, thus showing the importance but also the vast opportunities given by tuning the thermodynamic features of reversible covalent reactions. ${ }^{79,80}$ We have used the fact that oximes are thermodynamically more stable than acylhydrazones to operate a directed acylhydrazone-to-oxime exchange reaction. ${ }^{41,81,82}$ Using methoxyamine, we have been able to demonstrate the principle of chemically-triggered DNA decomplexation that results from the conversion of active cationic multivalent systems into inactive neutral assemblies through DCvC (Figure 9). ${ }^{68}$ 


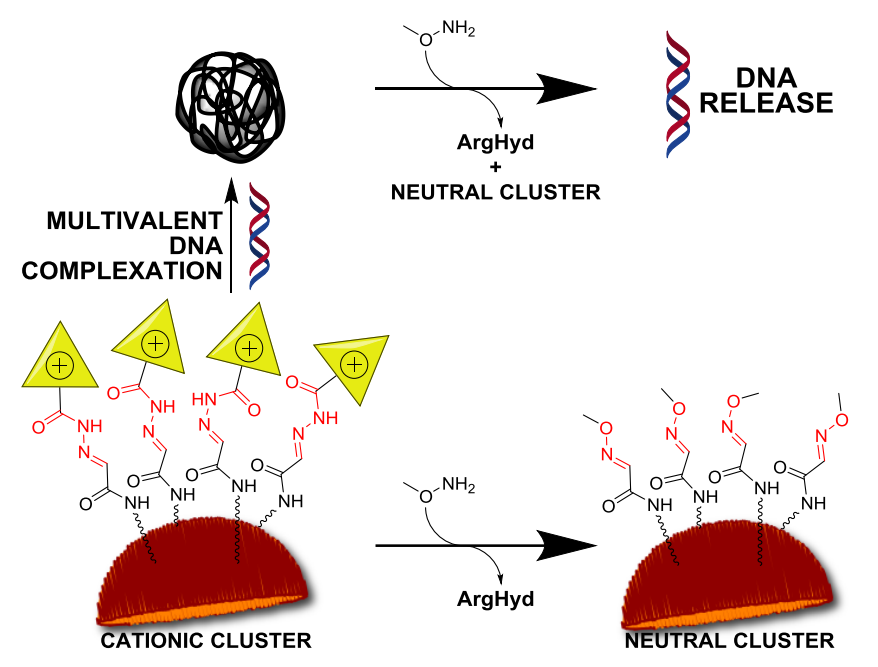

Figure 9. Principle of chemically-triggered DNA decomplexation by DCvC. Adapted with permission from ref. 68. Copyright 2015 Wiley-VCH.

\section{DYNAMIC COVALENT TARGETING}

Cell membranes contain a number of naturally occurring reactive groups at their surfaces which may be used to achieve selective membrane binding through dynamic covalent bond formation. Boronic acids can readily react with saccharides that are naturally present on membrane-bound glycoproteins. Such transient and traceless covalent bond formation can be harnessed to deliver pDNA $^{83}$ and polar proteins ${ }^{84,85}$ in mammalian cells (Figure 10A). Interestingly, some benzoxaboroles ${ }^{85}$ and heterocyclic boronic acids ${ }^{86}$ have shown selectivity for sialic acids that are abundant in the glycocalyx of cancer cells. More recently, Gao and co-workers have used iminoboronate chemistry to target bacteria via specific binding to amine-presenting lipids (Figure 10B). ${ }^{87,88}$ 


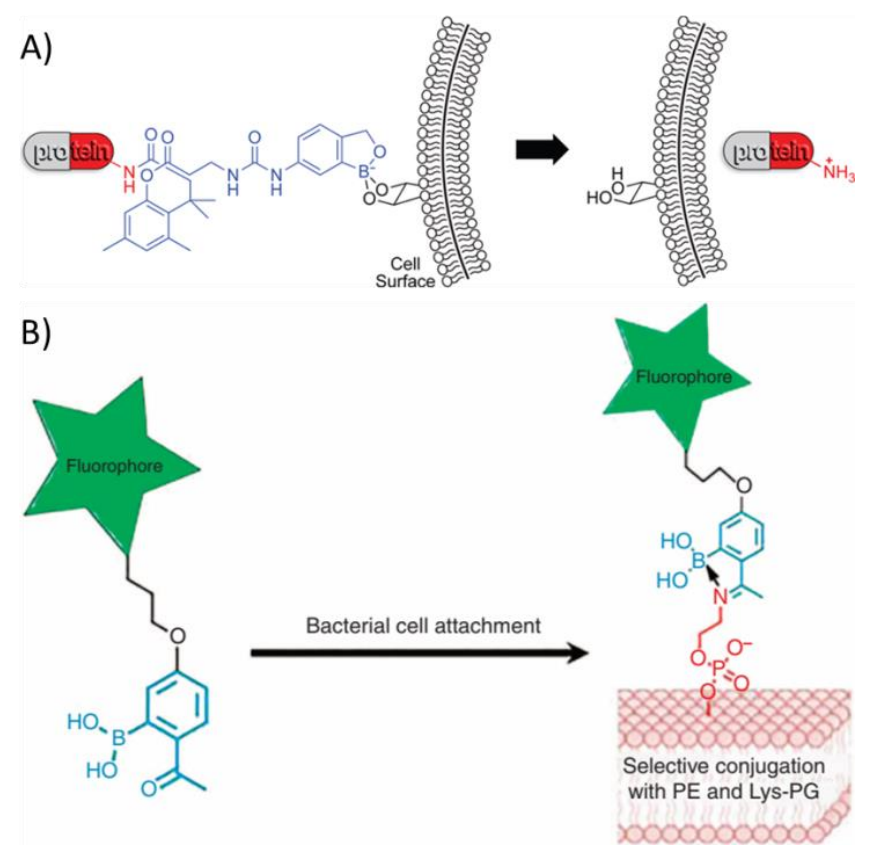

Figure 10. Selective covalent cell targeting through A) boronate ester formation and B) iminoboronate formation, for protein delivery and fluorescence labelling, respectively. PE: phosphatidylethanolamine; Lys-PG: lysylphosphatidylglycerol. Reprinted with permissions from ref. 84 (Copyright 2016 American Chemical Society) and 88 (Copyright 2015, Springer Nature).

Reversible covalent bonding with free thiols present in membrane proteins can also be harnessed for cell delivery, as illustrated with disulfide (vide supra) and diselenolane ${ }^{89}$ systems. Chemical biology techniques are nowadays available for artificially remodelling cell membranes to display reactive tags. ${ }^{90}$ Early on, the group of Bertozzi pioneered the use of oxime/hydrazone reactions on cell membranes displaying reactive carbonyls. ${ }^{91,92}$ More recently, Yousaf and co-workers showed that oxime ligation can be performed on an engineered cell surface in order to deliver nucleic acids through dynamic covalent targeting (Figure 11). ${ }^{93}$ The authors used delivery and fusion of engineered liposomes to introduce reactive ketones on cell membranes. A complementary lipoplex featuring oxyamines on the lipid outer shell then reacts with the modified cells, which lead to effective transfection. While the chemoselectivity of the covalent 
reactions enable precision delivery to tagged cells, the importance of the reversibility of this reaction remains in this case an open question. Eventually, in vivo applications will require selective insertion of exogenous lipids into the desired cell membranes - a difficult challenge ahead.

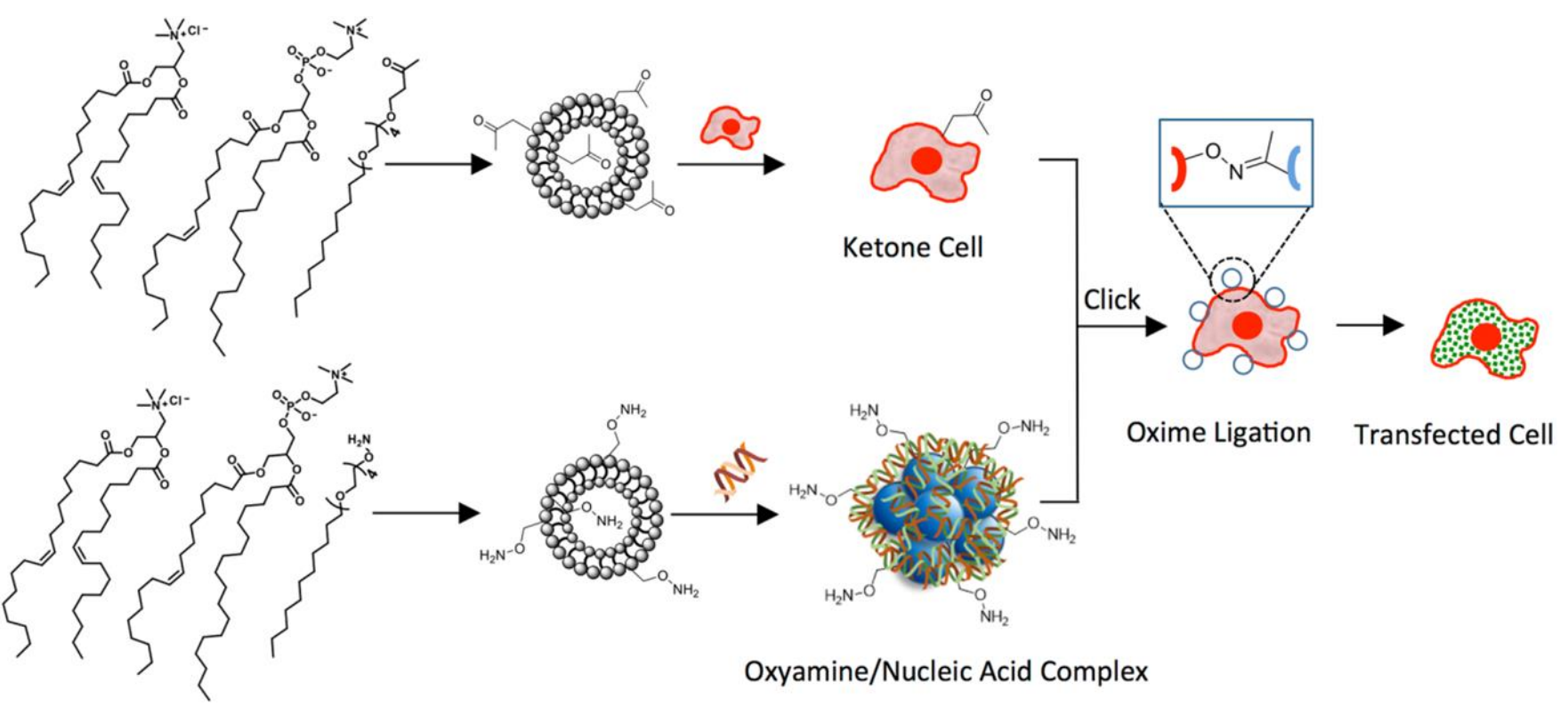

Figure 11. Principle of cell transfection operated chemoselectively through oxime bond formation between engineered cells displaying ketones and lipoplexes featuring oxyamines. Reproduced with permission from ref. 93. Copyright 2017 American Chemical Society.

\section{SUMMARY AND OUTLOOK}

The recent implementation of $\mathrm{DCvC}$ in delivery applications has followed three approaches: dynamic covalent bioconjugates, dynamic covalent vectors, and dynamic covalent targeting. Dynamic covalent bioconjugates are transient species that help stabilize and deliver the cargo while the final release triggered by covalent bond dissociation restores the activity of the untagged drug. Dynamic covalent vectors represent a class of "smart" vectors which i) are selffabricated by covalent self-assembly, ii) adapt their covalent structure through reversible bond 
formation/dissociation to the cargo and possibly to the biological barriers encountered during the delivery process, iii) are responsive to internal/external physico-chemical stimuli and can be deliberately manipulated by $\mathrm{DCvC}$ in order to trigger drug release. Finally, emerging reports also indicate the feasibility of chemo-selective and cell-specific dynamic covalent targeting. The concepts have now been established and illustrate the strong potential of such smart systems which are self-fabricated in a bottom-up fashion, self-fitted by adaptation, and responsive to physico-chemical stimuli in order to trigger vector degradation and concomitant active drug release - to outperform non-dynamic systems in delivery applications. Yet, several challenges lie ahead such as managing the toxicity of the reactive building blocks that are released upon dissociation, and of the adaptive self-assemblies. Clever design of integrated delivery system and fine-engineering of the thermodynamic features of the reversible covalent bond to achieve spatially- and temporally-controlled effective and safe drug release will be required for the successful translation into practical applications.

\section{AUTHOR INFORMATION}

\section{Corresponding Author}

*E-mail: Sebastien.Ulrich@enscm.fr

\section{ORCID}

Sébastien Ulrich: 0000-0002-6080-3345

\section{Funding Sources}

LabEx CheMISyst (ANR-10-LABX-05-01), and ANR (ANR-17-CE07-0042-01).

\section{Biographical Information}


Sébastien Ulrich carried out his PhD with Prof. Jean-Marie Lehn (Université de Strasbourg, France), and post-docs with Prof. Harry L. Anderson (Oxford University, UK) and Prof. Eric T. Kool (Stanford University, CA, USA). In 2011 he joined the group of Prof. Pascal Dumy, first in Grenoble, then in Montpellier, France where he was recruited by the CNRS in 2012 to develop his current research interests in the field of supramolecular bioorganic chemistry. In 2017, he was awarded the CNRS Bronze Medal.

\section{DEDICATION}

Dedicated to Professor Jean-Marie Lehn, inspiring mentor, on the occasion of his $80^{\text {th }}$ birthday.

\section{ACKNOWLEDGMENT}

I warmly thank all my co-workers who contributed to the works described here. Funding from the LabEx CheMISyst (ANR-10-LABX-05-01), and the ANR (ANR-17-CE07-0042-01) are acknowledged.

\section{REFERENCES}

(1) Zhang, W.; Jin, Y.: Dynamic Covalent Chemistry: Principles, Reactions, and Applications; Wiley-VCH: Weinheim, 2017.

(2) Herrmann, A. Dynamic combinatorial/covalent chemistry: a tool to read, generate and modulate the bioactivity of compounds and compound mixtures. Chem. Soc. Rev. 2014, 43, 1899-1933.

(3) Jin, Y. H.; Yu, C.; Denman, R. J.; Zhang, W. Recent advances in dynamic covalent chemistry. Chem. Soc. Rev. 2013, 42, 6634-6654.

(4) Rowan, S. J.; Cantrill, S. J.; Cousins, G. R. L.; Sanders, J. K. M.; Stoddart, J. F. Dynamic covalent chemistry. Angew. Chem. Int. Ed. 2002, 41, 898-952. 
(5) Lehn, J. M. Perspectives in Chemistry-Aspects of Adaptive Chemistry and Materials. Angew. Chem. Int. Ed. 2015, 54, 3276-3289.

(6) Lehn, J.-M. From supramolecular chemistry towards constitutional dynamic chemistry and adaptive chemistry. Chem. Soc. Rev. 2007, 36, 151-160.

(7) Dynamic Combinatorial Chemistry; Wiley-VCH: Weinheim, 2010.

(8) Dynamic Combinatorial Chemistry in Drug Discovery, Bioorganic Chemistry, and Materials Science; John Wiley \& Sons: Hoboken, New Jersey, 2010.

(9) Corbett, P. T.; Leclaire, J.; Vial, L.; West, K. R.; Wietor, J. L.; Sanders, J. K. M.; Otto, S. Dynamic combinatorial chemistry. Chem. Rev. 2006, 106, 3652-3711.

(10) Zhang, Y.; Barboiu, M. Constitutional Dynamic Materials-Toward Natural Selection of Function. Chem. Rev. 2016, 116, 809-834.

(11) Roy, N.; Bruchmann, B.; Lehn, J. M. DYNAMERS: dynamic polymers as self-healing materials. Chem. Soc. Rev. 2015, 44, 3786-3807.

(12) Moulin, E.; Cormos, G.; Giuseppone, N. Dynamic combinatorial chemistry as a tool for the design of functional materials and devices. Chem. Soc. Rev. 2012, 41, 1031-1049.

(13) Giuseppone, N. Toward Self-Constructing Materials: A Systems Chemistry Approach. Acc. Chem. Res. 2012, 45, 2178-2188.

(14) West, K. R.; Otto, S. Reversible Covalent Chemistry in Drug Delivery. Curr. Drug Discov. Technol. 2005, 2, 123-160.

(15) Webber, M. J.; Langer, R. Drug delivery by supramolecular design. Chem. Soc. Rev. 2017, 46, 6600-6620.

(16) Kölmel, D. K.; Kool, E. T. Oximes and Hydrazones in Bioconjugation: Mechanism and Catalysis. Chem. Rev. 2017, 117, 10358-10376. 
Ulrich, S.; Boturyn, D.; Marra, A.; Renaudet, O.; Dumy, P. Oxime Ligation: A

Chemoselective Click-Type Reaction for Accessing Multifunctional Biomolecular Constructs.

Chem. Eur. J. 2014, 20, 34-41.

(18) Bandyopadhyay, A.; Gao, J. M. Iminoboronate Formation Leads to Fast and Reversible Conjugation Chemistry of alpha-Nucleophiles at Neutral pH. Chem. Eur. J. 2015, 21, 1474814752.

Kool, E. T.; Crisalli, P.; Chan, K. M. Fast Alpha Nucleophiles: Structures that Undergo Rapid Hydrazone/Oxime Formation at Neutral pH. Org. Lett. 2014, 16, 1454-1457.

(20) Kool, E. T.; Park, D. H.; Crisalli, P. Fast Hydrazone Reactants: Electronic and Acid/Base Effects Strongly Influence Rate at Biological pH. J. Am. Chem. Soc. 2013, 135, $17663-17666$.

(21) Crisalli, P.; Kool, E. T. Importance of ortho Proton Donors in Catalysis of Hydrazone Formation. Org. Lett. 2013, 15, 1646-1649.

(22) Crisalli, P.; Kool, E. T. Water-soluble Organocatalysts for Hydrazone and Oxime Formation. J. Org. Chem. 2013, 78, 1184-1189.

(23) Dirksen, A.; Dawson, P. E. Rapid Oxime and Hydrazone Ligations with Aromatic Aldehydes for Biomolecular Labeling. Bioconjugate Chem. 2008, 19, 2543-2548.

(24) Dirksen, A.; Dirksen, S.; Hackeng, T. M.; Dawson, P. E. Nucleophilic catalysis of hydrazone formation and transimination: Implications for dynamic covalent chemistry. $J$. Am. Chem. Soc. 2006, 128, 15602-15603.

(25) Dirksen, A.; Hackeng, T. M.; Dawson, P. E. Nucleophilic catalysis of oxime ligation. Angew. Chem. Int. Ed. 2006, 45, 7581-7584. 
(26) Larsen, D.; Kietrys, A. M.; Clark, S. A.; Park, H. S.; Ekebergh, A.; Kool, E. T. Exceptionally rapid oxime and hydrazone formation promoted by catalytic amine buffers with low toxicity. Chem. Sci. 2018, 9, 5252-5259.

(27) Karmakar, S.; Harcourt, E. M.; Hewings, D. S.; Scherer, F.; Lovejoy, A. F.; Kurtz, D. M.; Ehrenschwender, T.; Barandun, L. J.; Roost, C.; Alizadeh, A. A.; Kool, E. T. Organocatalytic removal of formaldehyde adducts from RNA and DNA bases. Nat. Chem. 2015, 7, 752-758.

(28) Mukherjee, S.; Ghosh, R. N.; Maxfield, F. R. Endocytosis. Physiol. Rev. 1997, 77, 759803.

(29) Black, S. P.; Sanders, J. K. M.; Stefankiewicz, A. R. Disulfide exchange: exposing supramolecular reactivity through dynamic covalent chemistry. Chem. Soc. Rev. 2014, 43, 18611872.

(30) Akgun, B.; Hall, D. G. Fast and Tight Boronate Formation for Click Bioorthogonal Conjugation. Angew. Chem. Int. Ed. 2016, 55, 3909-3913.

(31) Westmark, P. R.; Gardiner, S. J.; Smith, B. D. Selective monosaccharide transport through lipid bilayers using boronic acid carriers. J. Am. Chem. Soc. 1996, 118, 11093-11100.

(32) Westmark, P. R.; Smith, B. D. Boronic acids selectively facilitate glucose transport through a lipid bilayer. J. Am. Chem. Soc. 1994, 116, 9343-9344.

(33) Wu, X.; Busschaert, N.; Wells, N. J.; Jiang, Y. B.; Gale, P. A. Dynamic Covalent Transport of Amino Acids across Lipid Bilayers. J. Am. Chem. Soc. 2015, 137, 1476-1484.

(34) Stillwell, W. Facilitated Diffusion of Amino-Acids across Bimolecular LipidMembranes as a Model for Selective Accumulation of Amino-Acids in a Primordial Proto-Cell. Biosystems 1976, 8, 111-117. 
(35) Lostalé-Seijo, I.; Montenegro, J. Synthetic materials at the forefront of gene delivery. Nat. Rev. Chem. 2018, 2, 258-277.

(36) Lächelt, U.; Wagner, E. Nucleic Acid Therapeutics Using Polyplexes: A Journey of 50 Years (and Beyond). Chem. Rev. 2015, 115, 11043-11078.

(37) Mastrobattista, E.; van der Aa, M. A. E. M.; Hennink, W. E.; Crommelin, D. J. A. Artificial viruses: a nanotechnological approach to gene delivery. Nat. Rev. Drug Discovery 2006, 5, 115-121.

(38) Bartolami, E.; Bouillon, C.; Dumy, P.; Ulrich, S. Bioactive clusters promoting cell penetration and nucleic acid complexation for drug and gene delivery applications: from designed to self-assembled and responsive systems. Chem. Commun. 2016, 52, 4257-4273.

(39) Miyata, K.; Nishiyama, N.; Kataoka, K. Rational design of smart supramolecular assemblies for gene delivery: chemical challenges in the creation of artificial viruses. Chem. Soc. Rev. 2012, 41, 2562-2574.

(40) Wagner, E. Polymers for siRNA Delivery: Inspired by Viruses to be Targeted, Dynamic, and Precise. Acc. Chem. Res. 2012, 45, 1005-1013.

(41) Bouillon, C.; Paolantoni, D.; Rote, J. C.; Bessin, Y.; Peterson, L. W.; Dumy, P.; Ulrich, S. Degradable hybrid materials based on cationic acylhydrazone dynamic covalent polymers promote DNA complexation through multivalent interactions. Chem. Eur. J. 2014, 20, 1470514714.

(42) Liu, Y.; Lehn, J. M.; Hirsch, A. K. H. Molecular Biodynamers: Dynamic Covalent Analogues of Biopolymers. Acc. Chem. Res. 2017, 50, 376-386. 
Bouillon, C.; Bessin, Y.; Poncet, F.; Gary-Bobo, M.; Dumy, P.; Barboiu, M.; Bettache,

N.; Ulrich, S. Biomolecular dynamic covalent polymers for DNA complexation and siRNA delivery. J. Mater. Chem. B 2018, 6, 7239-7246.

(44) Priegue, J. M.; Lostale-Seijo, I.; Crisan, D.; Granja, J. R.; Fernandez-Trillo, F.; Montenegro, J. Different-Length Hydrazone Activated Polymers for Plasmid DNA Condensation and Cellular Transfection. Biomacromolecules 2018, 19, 2638-2649.

(45) Priegue, J. M.; Crisan, D. N.; Martinez-Costas, J.; Granja, J. R.; Fernandez-Trillo, F.; Montenegro, J. In Situ Functionalized Polymers for siRNA Delivery. Angew. Chem. Int. Ed. 2016, 55, 7492-7495.

(46) Fuertes, A.; Juanes, M.; Granja, J. R.; Montenegro, J. Supramolecular functional assemblies: dynamic membrane transporters and peptide nanotubular composites. Chem. Commun. 2017, 53, 7861-7871.

(47) Louzao, I.; Garcia-Fandino, R.; Montenegro, J. Hydrazone-modulated peptides for efficient gene transfection. J. Mater. Chem. B 2017, 5, 4426-4434.

(48) Lostale-Seijo, I.; Louzao, I.; Juanes, M.; Montenegro, J. Peptide/Cas9 nanostructures for ribonucleoprotein cell membrane transport and gene edition. Chem. Sci. 2017, 8, 7923-7931.

(49) Gehin, C.; Montenegro, J.; Bang, E.-K.; Cajaraville, A.; Takayama, S.; Hirose, H.; Futaki, S.; Matile, S.; Riezman, H. Dynamic Amphiphile Libraries To Screen for the "Fragrant" Delivery of siRNA into HeLa Cells and Human Primary Fibroblasts. J. Am. Chem. Soc. 2013, $135,9295-9298$.

(50) Montenegro, J.; Bang, E. K.; Sakai, N.; Matile, S. Synthesis of an Enlarged Library of Dynamic DNA Activators with Oxime, Disulfide and Hydrazone Bridges. Chem. Eur. J. 2012, 18, 10436-10443. 
DNA activators in lipid bilayers: implications on transport, sensing and cellular uptake. Org. Biomol. Chem. 2011, 9, 2641-2647.

(52) Montenegro, J.; Bonvin, P.; Takeuchi, T.; Matile, S. Dynamic Octopus Amphiphiles as Powerful Activators of DNA Transporters: Differential Fragrance Sensing and Beyond. Chem. Eur. J. 2010, 16, 14159-14166.

(53) Bartolami, E.; Bessin, Y.; Bettache, N.; Gary-Bobo, M.; Garcia, M.; Dumy, P.; Ulrich, S. Multivalent DNA recognition by self-assembled clusters: deciphering structural effects by fragments screening and evaluation as siRNA vectors. Org. Biomol. Chem. 2015, 13, 9427-9438.

(54) McKenzie, D. L.; Kwok, K. Y.; Rice, K. G. A potent new class of reductively activated peptide gene delivery agents. J. Biol. Chem. 2000, 275, 9970-9977.

(55) McKenzie, D. L.; Smiley, E.; Kwok, K. Y.; Rice, K. G. Low molecular weight disulfide cross-linking peptides as nonviral gene delivery carriers. Bioconjugate Chem. 2000, 11, 901-909. (56) Blessing, T.; Remy, J. S.; Behr, J. P. Monomolecular collapse of plasmid DNA into stable virus-like particles. Proc. Natl. Acad. Sci. USA 1998, 95, 1427-1431.

(57) Oupicky, D.; Parker, A. L.; Seymour, L. W. Laterally stabilized complexes of DNA with linear reducible polycations: Strategy for triggered intracellular activation of DNA delivery vectors. J. Am. Chem. Soc. 2002, 124, 8-9.

(58) Bode, S. A.; Wallbrecher, R.; Brock, R.; van Hest, J. C. M.; Lowik, D. W. P. M. Activation of cell-penetrating peptides by disulfide bridge formation of truncated precursors. Chem. Commun. 2014, 50, 415-417. 
Bang, E. K.; Gasparini, G.; Molinard, G.; Roux, A.; Sakai, N.; Matile, S. Substrate-

Initiated Synthesis of Cell-Penetrating Poly(disulfide)s. J. Am. Chem. Soc. 2013, 135, 20882091.

(60) Gasparini, G.; Matile, S. Protein delivery with cell-penetrating poly(disulfide)s. Chem. Commun. 2015, 51, 17160-17162.

(61) Chuard, N.; Gasparini, G.; Moreau, D.; Lorcher, S.; Palivan, C.; Meier, W.; Sakai, N.; Matile, S. Strain-Promoted Thiol-Mediated Cellular Uptake of Giant Substrates: Liposomes and Polymersomes. Angew. Chem. Int. Ed. 2017, 56, 2947-2950.

(62) Bang, E. K.; Lista, M.; Sforazzini, G.; Sakai, N.; Matile, S. Poly(disulfide)s. Chem. Sci. 2012, 3, 1752-1763.

(63) Drozdz, W.; Walczak, A.; Bessin, Y.; Gervais, V.; Cao, X. Y.; Lehn, J. M.; Ulrich, S.; Stefankiewicz, A. R. Multivalent Metallosupramolecular Assemblies as Effective DNA Binding Agents. Chem. Eur. J. 2018, 24, 10802-10811.

(64) Drożdż, W.; Bessin, Y.; Gervais, V.; Cao, X.-Y.; Lehn, J.-M.; Stefankiewicz, A. R.; Ulrich, S. Switching multivalent DNA complexation using metallo-controlled cationic supramolecular self-assemblies. Chem. Eur. J. 2018, 24, 1518-1521.

(65) Gallego-Yerga, L.; Benito, J. M.; Blanco-Fernandez, L.; Martinez-Negro, M.; Velaz, I.;

Aicart, E.; Junquera, E.; Mellet, C. O.; de Ilarduya, C. T.; Fernandez, J. M. G. PlasmidTemplated Control of DNA-Cyclodextrin Nanoparticle Morphology through Molecular Vector Design for Effective Gene Delivery. Chem. Eur. J. 2018, 24, 3825-3835.

(66) Evenou, P.; Rossignol, J.; Pembouong, G.; Gothland, A.; Colesnic, D.; Barbeyron, R.; Rudiuk, S.; Marcelin, A. G.; Menand, M.; Baigl, D.; Calvez, V.; Bouteiller, L.; Sollogoub, M. Bridging beta-Cyclodextrin Prevents Self-Inclusion, Promotes Supra-molecular Polymerization, 
and Promotes Cooperative Interaction with Nucleic Acids. Angew. Chem. Int. Ed. 2018, 57, 7753-7758.

(67) Liu, X. X.; Zhou, J. H.; Yu, T. Z.; Chen, C.; Cheng, Q.; Sengupta, K.; Huang, Y. Y.; Li, H. T.; Liu, C.; Wang, Y.; Posocco, P.; Wang, M. H.; Cui, Q.; Giorgio, S.; Fermeglia, M.; Qu, F. Q.; Pricl, S.; Shi, Y. H.; Liang, Z. C.; Rocchi, P.; Rossi, J. J.; Peng, L. Adaptive Amphiphilic Dendrimer-Based Nanoassemblies as Robust and Versatile siRNA Delivery Systems. Angew. Chem. Int. Ed. 2014, 53, 11822-11827.

(68) Bartolami, E.; Bessin, Y.; Gervais, V.; Dumy, P.; Ulrich, S. Dynamic expression of DNA complexation with self-assembled biomolecular clusters. Angew. Chem. Int. Ed. 2015, 54, 10183-10187.

Marin, L.; Ailincai, D.; Cahn, M.; Stan, D.; Constantinescu, C. A.; Ursu, L.; Doroftei, F.; Pinteala, M.; Simionescu, B. C.; Barboiu, M. Dynameric Frameworks for DNA Transfection. ACS Biomater. Sci. Eng. 2016, 2, 104-111.

(70) Catana, R.; Barboiu, M.; Moleavin, I.; Clima, L.; Rotaru, A.; Ursu, E.-L.; Pinteala, M. Dynamic constitutional frameworks for DNA biomimetic recognition. Chem. Commun. 2015, 51, 2021-2024.

(71) Turin-Moleavin, I. A.; Doroftei, F.; Coroaba, A.; Peptanariu, D.; Pinteala, M.; Salic, A.; Barboiu, M. Dynamic constitutional frameworks (DCFs) as nanovectors for cellular delivery of DNA. Org. Biomol. Chem. 2015, 13, 9005-9011.

(72) Clima, L.; Peptanariu, D.; Pinteala, M.; Salic, A.; Barboiu, M. DyNAvectors: dynamic constitutional vectors for adaptive DNA transfection. Chem. Commun. 2015, 51, 17529-17531. Mogaki, R.; Hashim, P. K.; Okuro, K.; Aida, T. Guanidinium-based "molecular glues" for modulation of biomolecular functions. Chem. Soc. Rev. 2017, 46, 6480-6491. 
(74) Hashim, P. K.; Okuro, K.; Sasaki, S.; Hoashi, Y.; Aida, T. Reductively Cleavable Nanocaplets for siRNA Delivery by Template-Assisted Oxidative Polymerization. J. Am. Chem. Soc. 2015, 137, 15608-15611.

(75) Abegg, D.; Gasparini, G.; Hoch, D. G.; Shuster, A.; Bartolami, E.; Matile, S.; Adibekian, A. Strained Cyclic Disulfides Enable Cellular Uptake by Reacting with the Transferrin Receptor. J. Am. Chem. Soc. 2017, 139, 231-238.

(76) Zong, L. L.; Bartolami, E.; Abegg, D.; Adibekian, A.; Sakai, N.; Matile, S. Epidithiodiketopiperazines: Strain-Promoted Thiol-Mediated Cellular Uptake at the Highest Tension. ACS Central Sci. 2017, 3, 449-453.

(77) Gasparini, G.; Sargsyan, G.; Bang, E. K.; Sakai, N.; Matile, S. Ring Tension Applied to Thiol-Mediated Cellular Uptake. Angew. Chem. Int. Ed. 2015, 54, 7328-7331.

(78) Bauhuber, S.; Hozsa, C.; Breunig, M.; Gopferich, A. Delivery of Nucleic Acids via Disulfide-Based Carrier Systems. Adv. Mater. 2009, 21, 3286-3306.

(79) Gasparini, G.; Bang, E. K.; Molinard, G.; Tulumello, D. V.; Ward, S.; Kelley, S. O.; Roux, A.; Sakai, N.; Matile, S. Cellular Uptake of Substrate-Initiated Cell-Penetrating Poly(disulfide)s. J. Am. Chem. Soc. 2014, 136, 6069-6074.

(80) Chuard, N.; Gasparini, G.; Roux, A.; Sakai, N.; Matile, S. Cell-penetrating poly(disulfide)s: the dependence of activity, depolymerization kinetics and intracellular localization on their length. Org. Biomol. Chem. 2015, 13, 64-67.

(81) Drozdz, W.; Bouillon, C.; Kotras, C.; Richeter, S.; Barboiu, M.; Clement, S.; Stefankiewicz, A. R.; Ulrich, S. Generation of Multicomponent Molecular Cages using Simultaneous Dynamic Covalent Reactions. Chem. Eur. J. 2017, 23, 18010-18018. 
Bartolami, E.; Knoops, J.; Bessin, Y.; Fossépré, M.; Chamieh, J.; Dumy, P.; Surin, M.;

Ulrich, S. One-Pot Self-Assembly of Peptide-Based Cage-Type Nanostructures Using Orthogonal Ligations. Chem. Eur. J. 2017, 23, 14323-14331.

(83) Peng, Q.; Chen, F. J.; Zhong, Z. L.; Zhuo, R. X. Enhanced gene transfection capability of polyethylenimine by incorporating boronic acid groups. Chem. Commun. 2010, 46, 58885890.

(84) Andersen, K. A.; Smith, T. P.; Lomax, J. E.; Raines, R. T. Boronic Acid for the Traceless Delivery of Proteins into Cells. ACS Chem. Biol. 2016, 11, 319-323.

(85) Ellis, G. A.; Palte, M. J.; Raines, R. T. Boronate-Mediated Biologic Delivery. J. Am. Chem. Soc. 2012, 134, 3631-3634.

$$
\text { Matsumoto, A.; Stephenson-Brown, A. J.; Khan, T.; Miyazawa, T.; Cabral, H.; Kataoka, }
$$
K.; Miyahara, Y. Heterocyclic boronic acids display sialic acid selective binding in a hypoxic tumor relevant acidic environment. Chem. Sci. 2017, 8, 6165-6170.

$$
\text { McCarthy, K. A.; Kelly, M. A.; Li, K. C.; Cambray, S.; Hosseini, A. S.; van Opijnen, T.; }
$$

Gao, J. M. Phage Display of Dynamic Covalent Binding Motifs Enables Facile Development of Targeted Antibiotics. J. Am. Chem. Soc. 2018, 140, 6137-6145.

$$
\text { Bandyopadhyay, A.; McCarthy, K. A.; Kelly, M. A.; Gao, J. M. Targeting bacteria via }
$$
iminoboronate chemistry of amine-presenting lipids. Nat. Commun. 2015, 6.

(89) Chuard, N.; Poblador-Bahamonde, A. I.; Zong, L. L.; Bartolami, E.; Hildebrandt, J.; Weigand, W.; Sakai, N.; Matile, S. Diselenolane-mediated cellular uptake. Chem. Sci. 2018, 9 , 1860-1866.

(90) Prescher, J. A.; Dube, D. H.; Bertozzi, C. R. Chemical remodelling of cell surfaces in living animals. Nature 2004, 430, 873-877. 
(91) Hang, H. C.; Bertozzi, C. R. Chemoselective approaches to glycoprotein assembly. Acc. Chem. Res. 2001, 34, 727-736.

(92) Mahal, L. K.; Yarema, K. J.; Bertozzi, C. R. Engineering chemical reactivity on cell surfaces through oligosaccharide biosynthesis. Science 1997, 276, 1125-1128.

(93) O'Brien, P. J.; Elahipanah, S.; Rogozhnikov, D.; Yousaf, M. N. Bio-Orthogonal Mediated Nucleic Acid Transfection of Cells via Cell Surface Engineering. ACS Cent. Sci. 2017, 3, 489-500. 